\title{
The school library and e-learning platforms
}

\author{
Monica Morscheck \\ Head Librarian and E-Learning Coordinator \\ British International School, Phuket, Thailand \\ www.bisphuket.ac.th \\ mmorscheck@bisphuket.ac.th
}

\begin{abstract}
The teacher-librarian should be the most effective weapon for collaborative teaching and learning within a school. Teacher-librarians do struggle to find time to effectively plan for the cooperative teaching and learning activities. Often school libraries run their own website as they struggle to offer a digital 24/7 library service for its users. The school library website makes it easier for the teacher-librarian to manage the information delivery but isolates the content. The teacher-librarian managed website is often not an effective tool for cooperative planning and teaching.
\end{abstract}

This paper will look at how the teacher-librarian can use e-learning platforms to deliver a digital 24/7 library service, and in addition, offer a great collaborative space for effective cooperative planning and teaching. This paper will focus on examples of practice in two schools. The first school is a New South Wales government high school and uses Moodle as the e-learning platform. The second school is an international K-12 private school and uses StudyWiz as the e-learning platform.

\section{Introduction}

As teacher-librarians (and school librarians) we know we should be practicing collaboration in the schools where we work. It is proven that teacher-librarians, who plan with class teachers for student instruction and collection development, make a direct and positive impact on student learning outcomes. However, studies have shown (Webb and Doll, 1999; Montiel-Overall, 2005) over and over that one of the greatest hindrances to engaging in effective collaboration is the limited, or lack of time, teacher-librarians have to prepare with teachers. E-learning platforms can be used as effective collaboration planning spaces (Farmer, 2009).

\section{What are e-learning platforms?}

The e-learning platforms are interactive online services that allow students, teachers and parents to access coursework, information, tools and resources to support and enhance teaching, learning and management. E-learning platforms are most commonly referred to as virtual learning environments (VLE), but also may be called learning management systems (LMS) or course management systems. Examples of free (or open source) e-learning platforms include Moodle, eFront or Sakai. Examples of subscription e-learning platforms include Blackboard, StudyWiz, SecondLife or WebTrain.

\section{Why do schools and school libraries choose to use them?}

- E-learning enhances responsiveness - E-learning can reach an unlimited number of people virtually simultaneously.

- Messages are consistent or customized - Everyone gets the same content, presented in the same way, and it takes advantage of the universal Internet protocols, browsers and tools. Feedback can be instantaneous.

- Content is more timely and dependable - E-learning is web-enabled, and can be updated instantaneously, making the information more accurate and useful for a longer period of time.

- Learning is secure 24/7 - People can access e-learning anywhere and anytime via password protection. This approach makes an organisation's learning operations truly global.

(C) 2010 IASL, SLAQ and therein by the authors. Diversity Challenge Resilience: School Libraries in Action Proceedings of the $12^{\text {th }}$ Biennial School Library Association of Queensland, the $39^{\text {th }}$ International Association of School Librarianship Annual Conference incorporating the $14^{\text {th }}$ International Forum on Research in School Librarianship, Brisbane QLD Australia, 27 September - 1 October 2010. 
- Builds community - It enables people to build enduring communities of practice where they can come together to share knowledge and insight long after the programs end.

- Scalability - E-learning solutions are highly scalable. Platforms can move from 10 participants to 100 or even 100,000 participants with little effort or incremental cost (Chen, 2007).

E-learning platforms will allow teacher-librarians to embrace $21^{\text {st }}$ century skills into their libraries and classrooms, ensuring students share responsibility and ownership of their learning (Zumda, 2009).

\section{What can libraries include on the e-learning platform?}

Below are examples of e-learning library pages.

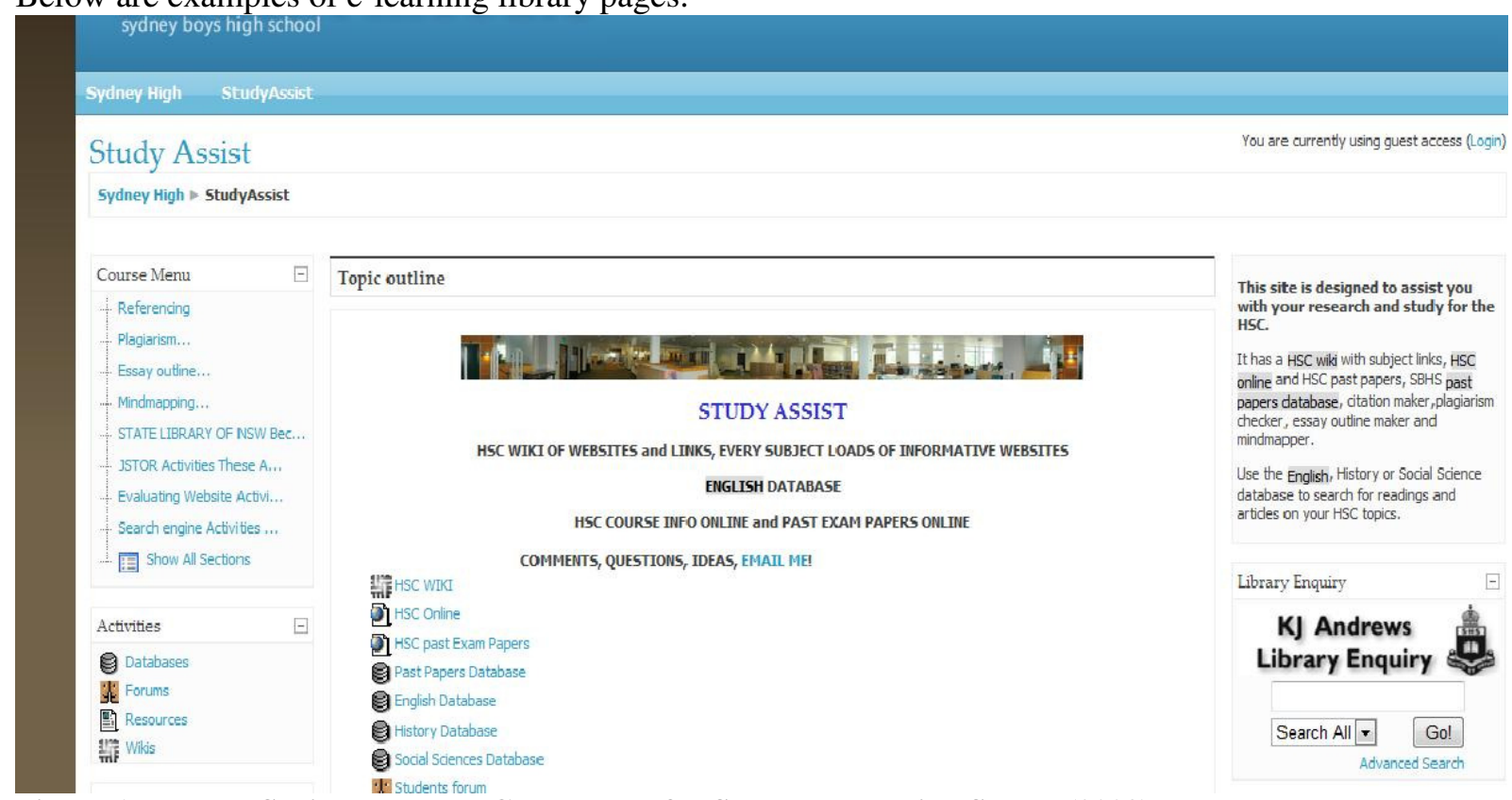

Figure 1: Moodle Senior Resource Centre page for Sydney Boys High School (2009)

Figure 1 shows a basic senior library setup using Moodle as the e-learning platform, making use of Moodle's wiki, forums and database tools.

(C) 2010 IASL, SLAQ and therein by the authors. Diversity Challenge Resilience: School Libraries in Action Proceedings of the $12^{\text {th }}$ Biennial School Library Association of Queensland, the $39^{\text {th }}$ International Association of School Librarianship Annual Conference incorporating the $14^{\text {th }}$ International Forum on Research in School Librarianship, Brisbane QLD Australia, 27 September - 1 October 2010. 

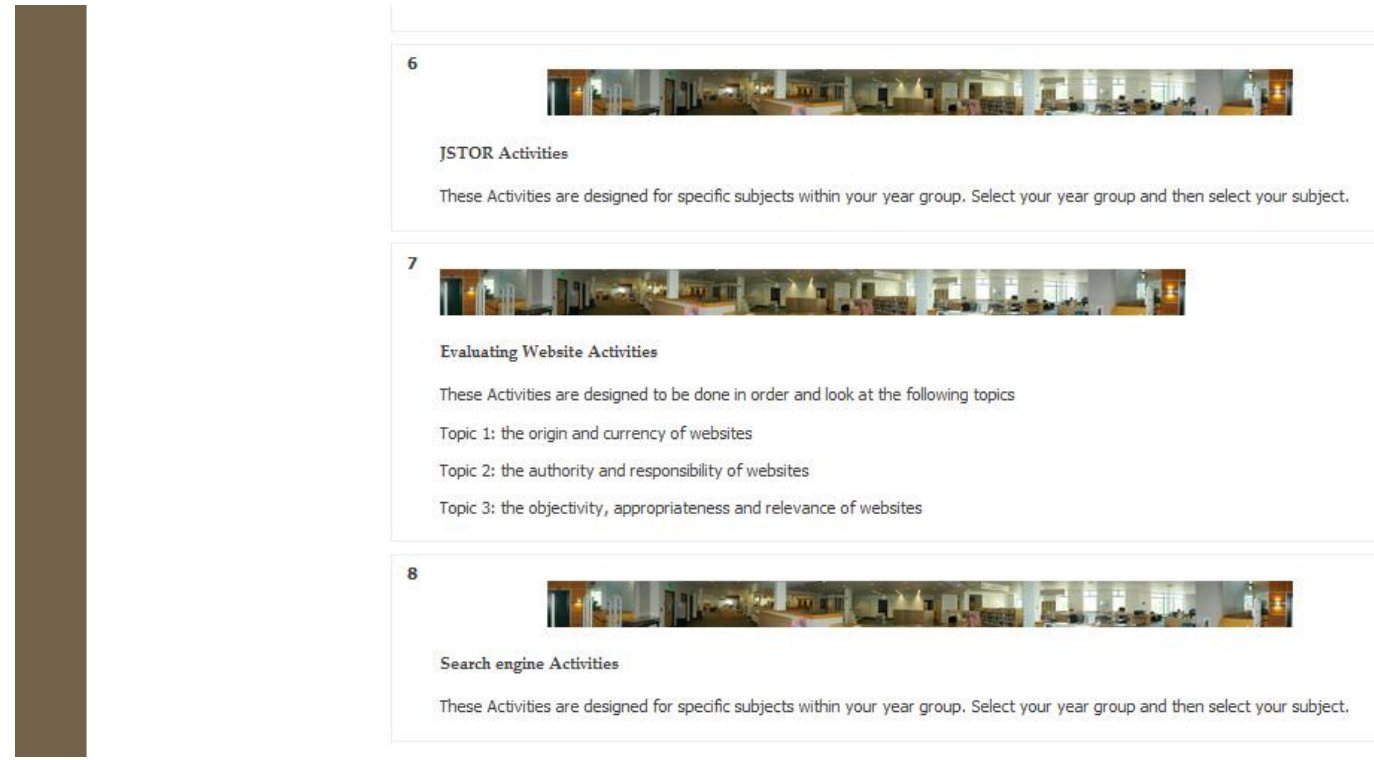

$\square$

$\square$

$\square$

Figure 2: Moodle Senior Resource Centre student work/activity space for Sydney Boys High School (2009)

Figure 2 shows basic activity space where student class work is loaded. Below, figures 3, 4 and 5 show a more advanced setup for the library on an e-learning platform.

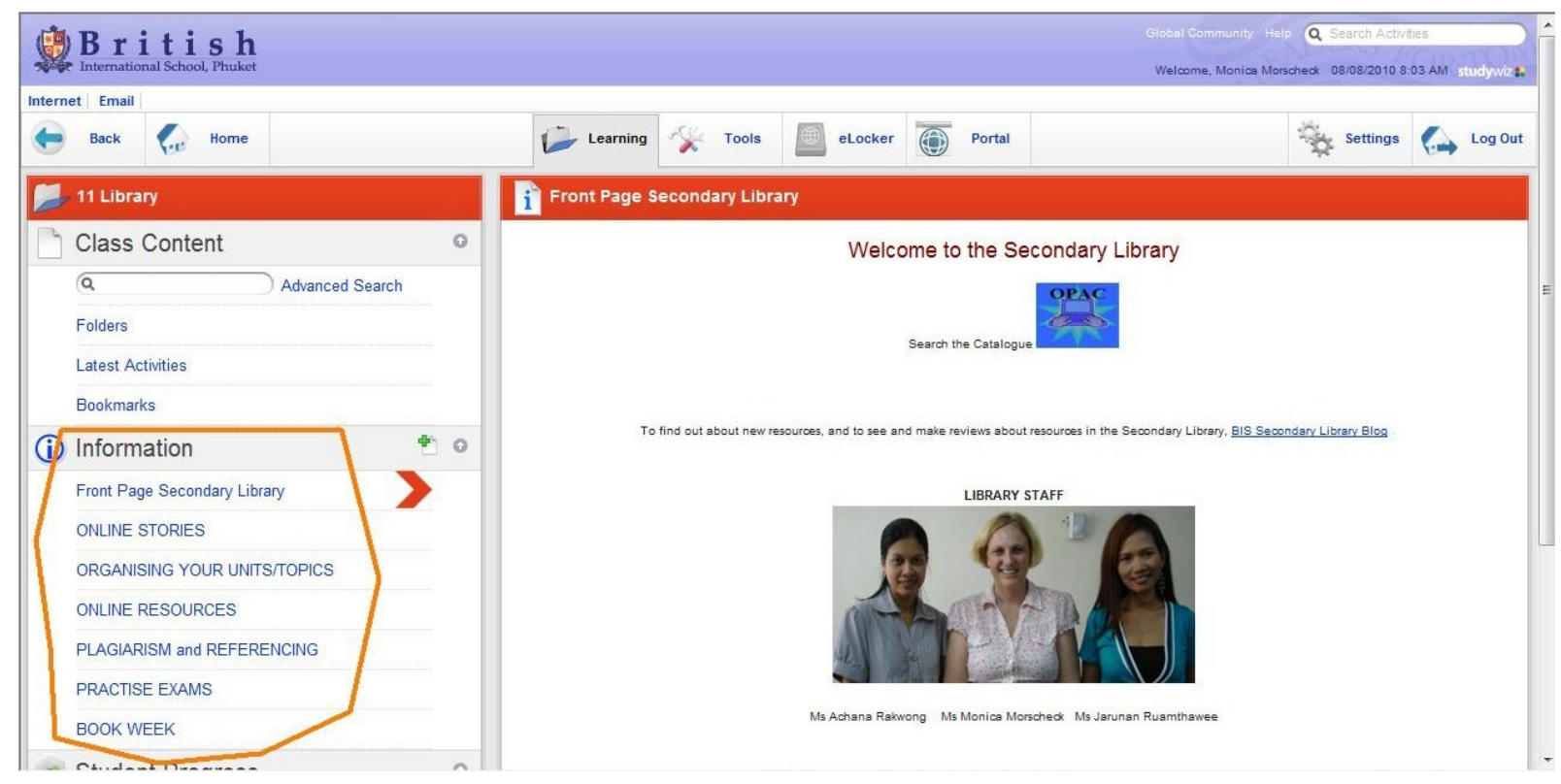

Figure 3: StudyWiz library page of the British International School, Phuket (2010)

Figures 3 is the library front page and circled in orange are the tabs for the information pages that give access to online resources for the students.

(C) 2010 IASL, SLAQ and therein by the authors. Diversity Challenge Resilience: School Libraries in Action Proceedings of the $12^{\text {th }}$ Biennial School Library Association of Queensland, the $39^{\text {th }}$ International Association of School Librarianship Annual Conference incorporating the $14^{\text {th }}$ International Forum on Research in School Librarianship, Brisbane QLD Australia, 27 September - 1 October 2010. 


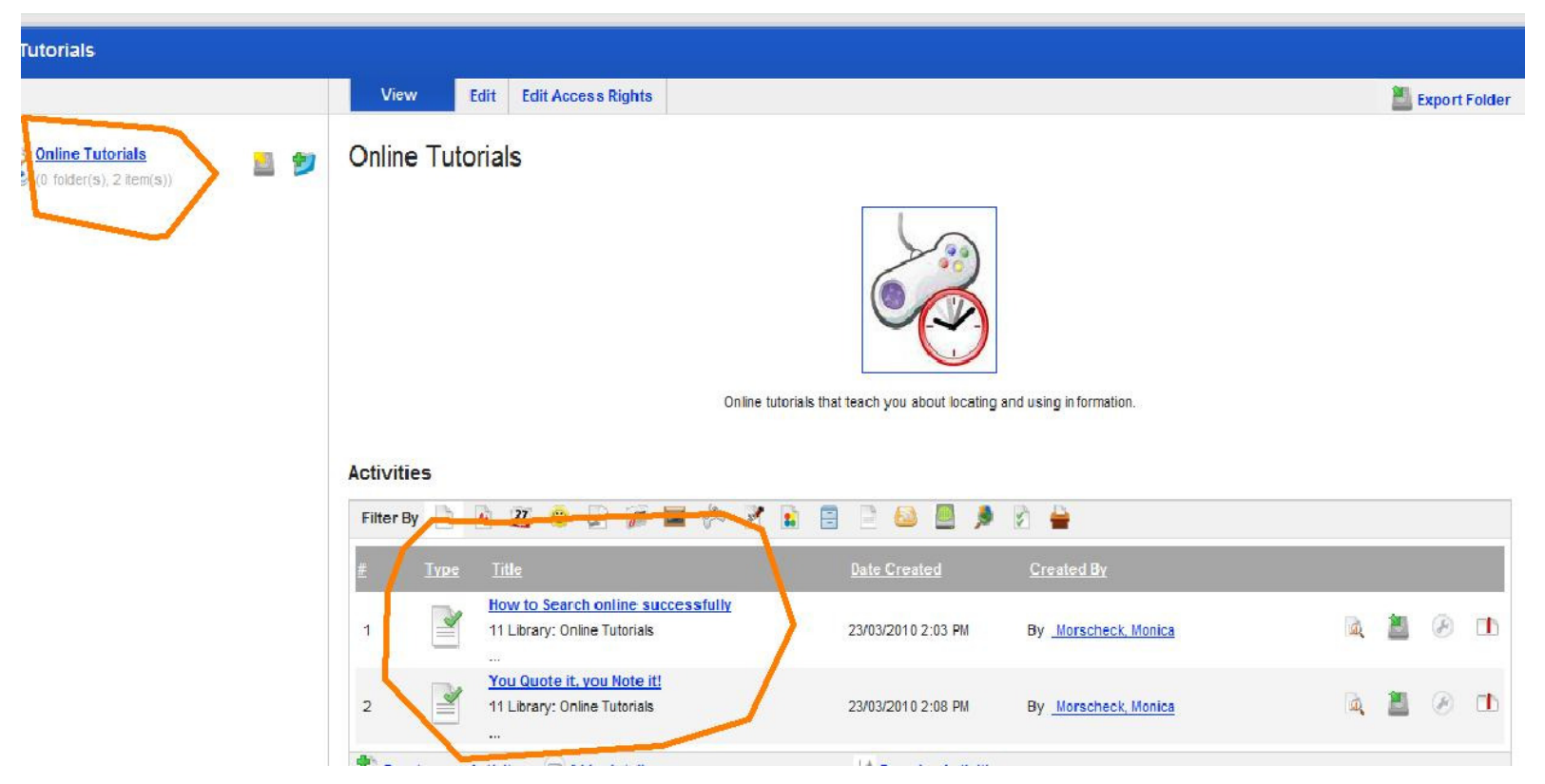

Figure 4: StudyWiz library student work/activity folder of the British International School, Phuket (2010)

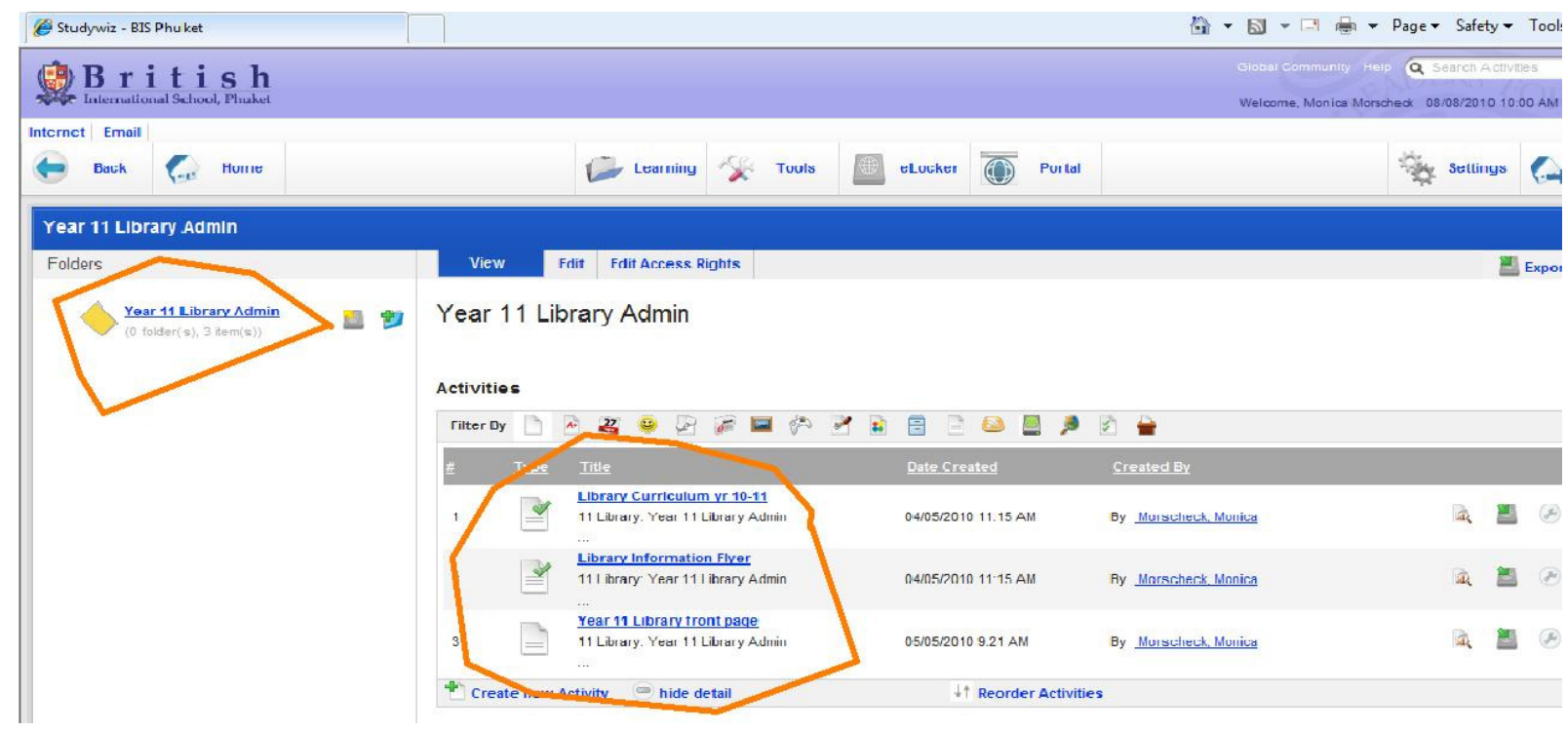

Figure 5: StudyWiz library administration content folder of the British International School, Phuket (2010)

Figure 4 shows the coursework area where the online activities are loaded for the students. Figure 5 shows the library administration material, including curriculum and library information, designed for parent viewing. Figures 3, 4 and 5 demonstrate that materials usually placed onto a school library website and a wiki or blog can just as easily be placed into an e-learning platform. Where schools have multiple teacher-librarians and library assistants, all library staff members can have rights to manipulate the content.

(C) 2010 IASL, SLAQ and therein by the authors. Diversity Challenge Resilience: School Libraries in Action Proceedings of the $12^{\text {th }}$ Biennial School Library Association of Queensland, the $39^{\text {th }}$ International Association of School Librarianship Annual Conference incorporating the $14^{\text {th }}$ International Forum on Research in School Librarianship, Brisbane QLD Australia, 27 September - 1 October 2010. 


\section{E-learning platform: Moodle and collaboration}

In February 2009 I was given a twelve month permanent casual position with the Department of Education and Training, New South Wales, as a teacher-librarian at Sydney Boys High School. My role was to setup a school funded Senior Resource Centre to be used exclusively by the students in year's ten to twelve. The Senior Resource Centre was to be a place of independent student study and as a collaborative teaching space. The school already had an existing library but its physical space was unable to provide for the school population, and being a selective school, the students were highly committed to their studies.

The school was already hosting a Moodle platform and it was being used by a range of teachers across the school. Several teachers were placing ninety (90) percent of their coursework on it, others were using it for homework delivery, several were using it as an online reference space and the majority were not using it at all. There was no formal school mandate to use it, but the senior students were very familiar with it and were avid users of technology.

The current school library did not have a dedicated web presence, although it did offer online subscription services which were accessed via the school intranet. My decision was to create a library course in Moodle, as the platform was already being used in the school. I also used Moodle for collaborative teaching and learning.

This was a new centre and I was a new teacher on staff. My first collaboration attempts relied on me creating the learning resource after consultation with the teacher. I choose to offer three areas of collaboration based on information literacy, online database skills (using the schools J-STOR subscription), website evaluation skills and search engine skills (see Figure 2). Once the curriculum and topic area was decided upon in consultation with the class teacher, I created the activity and uploaded it into Moodle as a class activity. The students came to the Senior Resource Centre to complete the task, with their teacher, and together the teacher and I would mark the task. The teachers that preferred this type of collaboration were themselves not confident Moodle users, thus benefiting from my teaching sessions as much as the students. One of the benefits of Moodle is its ability to create repositories of student work (Maikish, 2006) which we started to create in shared files after the activities were complete.

\section{E-learning platform: StudyWiz and collaboration}

In November 2009 I was given the opportunity to train on StudyWiz as part of my role as head librarian at the British International School, Phuket. The school had previously purchased a subscription and wished to implement a pilot program, with a small number of staff, in preparation for the whole school integration in the following academic year. The school caters to students from K-12 and wanted a platform for educational delivery as well as a tool for the greater school community communication. The current school library did not have a dedicated web presence; it did not offer online subscription services and the school had a very administration heavy school intranet. The school website, which was undergoing development, was to function as a marketing and promotional tool for the school. My decision was to create essentially a library page in StudyWiz, a platform that was intended to be used as the main technology teaching and learning tool in the school. I also used StudyWiz for collaborative teaching and learning.

My collaboration was offered in two ways. I continued to offer a system similar to my previous school, where I created the resources and activities. This worked well with teachers wanting to try StudyWiz but not having the advantage of attending workshops. The second level, and far more successful collaboration came when teachers and I shared teacher administrator rights for a class on StudyWiz. We could see what each other was doing, communicate to each other, and create whole units for curriculum topics. The

(C) 2010 IASL, SLAQ and therein by the authors. Diversity Challenge Resilience: School Libraries in Action Proceedings of the $12^{\text {th }}$ Biennial School Library Association of Queensland, the $39^{\text {th }}$ International Association of School Librarianship Annual Conference incorporating the $14^{\text {th }}$ International Forum on Research in School Librarianship, Brisbane QLD Australia, 27 September - 1 October 2010. 
teaching of these units was not restricted to any time or place, as students worked through the content and could approach either teacher for assistance. This type of collaboration is now practiced within the school. One of the best examples of collaboration via StudyWiz was the extended essay group. I, and the head of IB, share the administrator rights for the group, we upload information and resources, create the calendars and set deadlines, and twenty-three (23) teachers are users of the group supervising fifty-five (55) student users. As teachers we can all share and collaborate with each other.

\section{Conclusion}

E-learning platforms have been developed as online integrated spaces; integrated for sharing between student and teacher, parent and teacher, and also for teacher and teacher. Teacher-librarians can take advantage of these unique spaces to offer a 24/7 library environment that may have previously been delivered via a website and/or wiki and/or blog and/or intranet, and to offer collaborative planning space for teaching and learning resources for the students.

An additional advantage for teachers using e-learning platforms is to offer new users training, for the elearning platform, which can be delivered via the platform. E-learning platforms can overcome traditional barriers to professional development such as time for face-to face training, budgets and time. "The fact that participants also completed the course with a tangible ... e-learning resource of their own creation is also a positive feature as participants could point to the existence of a product which they could adapt/reuse as they wished" (Sutton, Booth, Aliku and O'Rourke, 2005, 88). Huber (2010) also highlights the benefits to sharing professional development via e-learning that include teachers uploading and sharing articles or papers from conferences they attended.

\section{The Future?}

Given that e-learning platforms are a relatively new educational tool being adopted in schools, there has been little research conducted into their benefit to the learning outcomes for students. It is said to be growing at thirty (30) percent a year (Arora, 2009). One research paper (Stone, Bongiorno, Hinegardner and Williams, 2004) that focused on a collaborative project between lecturers and librarians at Maryland University (US) using Blackboard; found that staff did take time initially to setup the course, with the use of many web2.0 tools, but had future plans to revise and update the coursework to be used again in the coming years. In another research paper (Roberts, 2006) at Kingston University (UK) using Blackboard; findings showed that eighty (80) percent of the students used it every day and enjoyed the flexibility of login on and off campus, so they could manage their private study. Often lecturers found students were reading ahead as facilitators loaded their course content. In the near future it is hoped further research will be conducted into e-learning platforms use in schools.

\section{References}

Abuzaid, R. and Singh, D. (2007). A framework for e-library services to support the e-learning environment in a secondary school: A case study, International Association of School Librarianship. Selected Papers from the Annual Conference, 1-7. Retrieved August 8, 2010, from Academic Research Library. (Document ID: 1563503961).

Arora, R. (2009). The K-12 online evolution. MultiMedia \& Internet@Schools, 16(6),14-18.

Chen, T. (2007). Strategy of promoting e-learning in school library. International Association of School Librarianship. Selected Papers from the Annual Conference, 1-12. Retrieved August 8, 2010, from Academic Research Library. (Document ID: 1563504671).

(C) 2010 IASL, SLAQ and therein by the authors. Diversity Challenge Resilience: School Libraries in Action Proceedings of the $12^{\text {th }}$ Biennial School Library Association of Queensland, the $39^{\text {th }}$ International Association of School Librarianship Annual Conference incorporating the $14^{\text {th }}$ International Forum on Research in School Librarianship, Brisbane QLD Australia, 27 September - 1 October 2010. 
Farmer, L. (2009). Library e-learning spaces. International Association of School Librarianship. Selected Papers from the Annual Conference, 1-12. Retrieved August 8, 2010, from Academic Research Library. (Document ID: 1968710571).

Huber, C. (2010). Professional learning 2.0. Educational Leadership, May, 41-46.

Jensen, L. (2010). Extend instruction outside the classroom: Take advantage of your learning management system. Computers in Libraries, 30(6), 76-78. Retrieved August 8, 2010, from ProQuest Computing. (Document ID: 2079830881).

Maikish, A. (2006). MOODLE: A free, easy and constructivist online learning tool. MultiMedia \& Internet@Schools, 13(3).

McFarland, S. S. (2007). Back to (virtual) school. Macworld, 24(8), 15.

Montiel-Overall, P. (2005). A theoretical understanding of teacher and librarian collaboration. School Libraries Worldwide, 11(2), July.

Roberts, L. (2006). Breaking down barriers. E-learning Age, pp.36-37. Retrieved August 8, 2010, from ABI/INFORM Global. (Document ID: 1151039071).

Stone, V., Bongiorno, R., Hinegardner, P. and Williams, M. (2004). Delivery of web-based instruction using Blackboard: a collaborative project. The Journal of the Medical Library Association, 92(3), 375-77.

Sutton, A., Booth, A., Ayiku, L. and O'Rourke, A. (2005). E-Folio: using e-learning to learn about elearning. Health Information and Libraries Journal, 22(2), 66-88.

Webb, N.L. \& Doll, C.A. (1999). Contributions of Library Power to collaborations between librarians and teachers. School Libraries Worldwide, 5(2), July.

Zmuda, A. (2009). Take the plunge into a $21^{\text {st }}$ century conception of learning. School Library Monthly, 26(3),16-18.

(C) 2010 IASL, SLAQ and therein by the authors. Diversity Challenge Resilience: School Libraries in Action Proceedings of the $12^{\text {th }}$ Biennial School Library Association of Queensland, the $39^{\text {th }}$ International Association of School Librarianship Annual Conference incorporating the $14^{\text {th }}$ International Forum on Research in School Librarianship, Brisbane QLD Australia, 27 September - 1 October 2010. 